\title{
Post-Harvest Management Practices among Rice Farmers in Imo State Nigeria
}

\author{
Egwuonwu H. Adeola
}

\section{ABSTRACT}

The study analyzed post-harvest management practices among rice farmers in Imo State, Nigeria. This work was inspired by inadequate availability of rice in the market for the masses which reduces food security, with belief that better management processes will reduce food losses. Random sampling procedure was used in selecting 127 rice farmers and data were collected using structured questionnaire was the main tool for data collection. Data collected were analyzed using descriptive (frequency, percentages and mean) and inferential statistics. Farmers identified delay in harvesting $(\mathbf{9 8 . 4 2 \%})$, lack of technical knowledge $(\mathbf{9 5 . 2 7 \%})$, dependency on traditional threshing methods $(\mathbf{9 4 . 4 8 \%})$, incomplete threshing $(91.30 \%)$, improper handling operations $(81.10 \%)$ as one of the various causes of post harvest losses in their rice production and processing in the study area. The post harvest management practices adopted by the farmers were as cutting the rice stalk $(98.42 \%)$, reaping the panicles $(94.48 \%)$, laying out the paddy-on-stalk $(93.70 \%)$, stacking it to dry $(92.12 \%)$ and stacking it to dry recording $(89.76 \%)$. The result from the multiple regression analysis showed that age, educational level, membership of cooperative, household size, farming experience, household size, farming experience and access to credit were found to have significantly influenced on the number of post harvests management practiced by farmers. Similarly, the farmers were also able to identify various constraints to post harvest management as lack of awareness of good post harvest practices and technology, inadequate machinery, lack of incentives to store rice It was therefore recommended that extension agents should be encouraged to increase their campaign on post harvest management practices of rice and organize more training on minimization of post harvest losses on rice.

Keywords: Rice, Post harvest losses, Post harvest practices, Post harvest management.

Published Online: July 16, 2020.

ISSN: $2684-5199$

DOI : $10.24018 /$ ejbio.2020.1.4.32

\section{H.A. Egwuonwu*} Imo State University, Nigeria. (e-mail: egwuonwu.helen @yahoo.com)

*Corresponding Author

\section{INTRODUCTION}

Rice is a major staple food in many African countries and it is one of the most cultivated crops in the world, also a staple food for over half of the world's population [14]. West African Rice Development Association [16] noted that rice sustains the livelihoods of 100 million people and its production has employed more than 20 million farmers in Africa. In Nigeria, rice (Oryza sativa) has been cultivated in some of the Northern parts of Nigeria since the $16^{\text {th }}$ century but its importance in the food economy of the Nation dates back to the early $20^{\text {th }}$ century. Today rice is virtually cultivated in all the Agro-ecological Zones in Nigeria on a relatively small scale [2]. However as the consumption level of rice increases, the level of production of rice in Nigeria has not met up with consumption, due to post harvest losses among rice farmers. There has been advocacy to develop the post harvest sector of agriculture in the country due to inherent post harvest losses in the production of crops [3].

The term post harvest loss was defined by [11] as the degradation in both quantity and quality of a food production from harvest to consumption. Quantity losses refer to those that result in the loss of the amount of a product and it is more common in developing countries. Post harvest losses in rice production is as a result of reduction in the amount of edible rice grain due to reduction in quality, edibility and availability of rice that prevents the rice grains from being consumed by people. Rice grain is lost at every step from harvesting operations to consumption. The reduction in the moisture content of rice grain and the removal of inedible portions such as husk and bran in the process of milling are not considered as post harvest losses [10]. Post harvest losses constitute a 
threat to household food and nutrition security as it leads to reduction in both quality and quantity of household food production. Approximately half of the populations in developing countries do not have access to adequate food supply; thus the food security problem is worsening [7]. There are many reasons for this, one of which is food losses occurring throughout the supply chain from production, harvesting, processing and marketing [4]. These losses lead to heavy loss of income and food supply to rural families, thereby threatening household food security and that, in the face of threat of household food security, malnutrition easily results. Improving post harvest management practices prove to be a necessity to increasing the amount of rice produce to meet the needs of the growing population.

Post harvest management can be seen as the stage of crop production immediately following harvest. Post harvest management practices in rice are the various handling, packaging and treatment that the rice grain undergoes before consumption. The instant a crop is removed from the ground, or separated from its parent plant, it begins to deteriorate. Post harvest operations in rice begin when the panicle is separated from the rice plant at harvest, harvesting is often considered the starting point of the post harvest management process. These processes include; harvesting, storage, by-products, drying and milling [15]. Harvesting activities refers to all operations carried out in the field which include cutting the rice stalk or reaping the panicles, either laying out the paddyon-stalk or stacking it to dry, and bundling for transport. Post harvest management in rice is of necessity because it will affect the total production of rice in a country and this will reduce the losses in both quality and quantity. However as the population of the country is increasing so the consumption level of rice increases, the level of production of rice in Nigeria has not met up with consumption, due to post harvest losses among rice farmers. These losses are largely caused by factors such as insect pests, poor logistics, fungal and bacterial diseases, poor management practices and inadequate storage facilities, mechanical damage. Proper post harvest management system will reduce losses in both rice quantity and quality thereby leading to increase in income of the farmer and food security. The effect of post harvest losses reduces food security and increase poverty level among farmers and their households, however, with good and proper management practices when adopted by farmers could have positive impact on the producers and also enhance sustainability.

Therefore, the specific objectives of the study were to describe the socio-economic characteristics of rice farmers in the study area; identified major causes of post harvest losses among rice farmers; described the post harvest management practices adopted by farmers in the study area and ascertained the constraints to post harvest management practices in rice production in the study area. The null hypothesis tested was the socio-economic characteristics of the farmer do not influence the post harvest management practices adopted by the farmer in the study area.

\section{RESEARCH METHODOLOGY}

This study was carried out in Ihitte/Uboma L.G.A of Imo State, Nigeria. Ihitte/Uboma L.G.A is made up of two separate independent clans, Ihitte and Uboma but which share common cultural backgrounds, and affinity. Its headquarters are in the town of Isinweke. It has an area of $104 \mathrm{~km}^{2}$ and a population of 120,744 at the 2006 census, of which about $80 \%$ of the population in the L.G.A is farmers [13]. This L.G.A is bounded in the East by Umuahia in Abia state, in the west by Ehime Mbano L.G.A of Imo State, in the south-west by Ahiazu Mbaise, in the North by Okigwe L.G.A and in the South by Obowo L.G.A of Imo State, also lies latitude $4^{\circ} 45^{\prime} \mathrm{N}$ and $7^{\circ} 15^{\prime} \mathrm{E}$ [6]. The population of the study comprised of all the rice farmers in Ihitte/Uboma Local Government Area of Imo State. A sample was drawn from local farmers in the study area. Multi-stage sampling procedure was used in the selection of respondents for the study. A purposive sampling procedure was used to draw five (5) autonomous communities that are known for rice production out of the 11 autonomous communities in the L.G.A. The autonomous communities: Uboma, Ikperejere, Onichi, Umuoma and Amainyi were selected for the study. Twenty six rice farmers were randomly selected from each of the five (5) stated communities, giving a sampling size of one hundred and thirty (130). Data for the study was generated from primary data using structured questionnaire that was administered to the 130 rice farmers. One hundred and twenty seven (127) useful questionnaires were used for data analysis. The data collected was analyzed with both descriptive statistical tools comprised of frequency table, percentages, and mean. The hypothesis was tested using multiple regression analysis. The implicit model of the regression is stated as follows:

$$
Y=f\left(X_{1}, X_{2}, X_{3}, X_{4}, X_{5}, X_{6}, X_{7}, X_{8},+e i\right)
$$

$\mathrm{Y}=$ number of adopted post harvest management practices;

$\mathrm{X}_{1}=$ age (years);

$\mathrm{X}_{2}=$ level of education (years);

$\mathrm{X}_{3}=$ membership of cooperative society $(1=$ yes, $0=$ no $)$;

$\mathrm{X}_{4}=$ gender $(1=$ male, $0=$ female $)$;

$\mathrm{X}_{5}=$ marital status $(1=$ married, $0=$ if otherwise $)$;

$\mathrm{X}_{6}=$ household size (number of persons);

$\mathrm{X}_{7}=$ farming experience (number of years);

$\mathrm{X}_{8}=$ access to credit $(1=$ access, $0=$ otherwise $)$;

$\mathrm{e}=$ error term.

\section{III.RESULTS AND DISCUSSION}

\section{A. Socio-economic characteristics of the rice farmers}

The result of the socio-economic characteristics of rice farmers in the study area is presented in Table 1. It indicates that the mean age of rice farmers was 44years. Majority $(75.59 \%)$ of the rice farmers were males, the finding implies that males are more involved in rice production than female, men could be able to withstand more than female the stress and strain involved in rice production. The result further reveals that majority $(67.72 \%)$ of the farmers had secondary education. Exposure to higher level of education is positively and significantly related to practice of better post harvest 
management [3], [8]. Greater proportions $(82.68 \%)$ of the farmers were married, the mean farming experience was 19.00 years. Majority (73.22\%) of the farmers had house hold size of 6-10 persons with the mean household size of 9 persons. This reveals that majority that involved in rice post harvest management practices have large household and this could contribute to labour availability of post harvest practices. This support the findings of [1] that farm families were in the range of 6 to 10 persons and that post harvest management practices are labour intensive, so having a large family could reduced the drudgery involved in these activities and lower the rate of post harvest losses in farm. Table 1 also shows that greater proportion $(77.17 \%)$ of the farmers in the area belong to one from of cooperative society or the other, reasonable proportion $(81.89 \%)$ of the farmers received 1-2 extension visits per month. The mean farm size was 1.47 hectares and greater proportion $(73.22 \%)$ of the farmers in the area have access to credit The finding implies that majority of farmers have access to credit facilities to promote better post-harvest management strategies to in rice production.

TABLE 1: SOCIO-ECONOMIC CHARACTERISTICS OF THE RICE FARMERS

\begin{tabular}{cccc}
\hline $\begin{array}{c}\text { Socio-economic } \\
\text { Characteristics }\end{array}$ & $\begin{array}{c}\text { Frequency/ } \\
\text { Mode }\end{array}$ & $\begin{array}{c}\text { Percen } \\
\text { tage }\end{array}$ & Mean \\
\hline Age (Years) & $41-50$ & 65.35 & 44.00 \\
Sex & $\begin{array}{c}\text { Male } \\
\text { Secondary }\end{array}$ & 75.59 & \\
Educational level & education & 67.72 & \\
Marital status & Married & 82.28 & \\
Farming experience & 20-30years & 51.18 & 19 years \\
Household size & $6-10$ & 73.22 & 9 \\
Cooperative member & Member & 77.17 & \\
No. of extension contact & $1-2$ times & 81.88 & \\
Farm size (hactare) & $1.0-1.5$ & 64.57 & 1.47 \\
Access to credit & Access & 73.22 & \\
\hline $127 ;$ Source: Fid Survey Data & 2019. & &
\end{tabular}

$\mathrm{N}=127 ;$ Source: Field Survey Data, 2019.

\section{B. Causes of post harvest losses among rice farmers}

The result on Table 2 shows the distribution based on major causes of post harvest losses among rice farmers. The finding shows that all $(100 \%)$ the farmers identified inadequate funding as one of the various causes of postharvest losses in their rice production and processing in the area. This is true as a lot of funding is required in the purchase of necessary inputs in rice production and processing. Incidentally, these farmers may not have access to financial resource for production. The finding shares view with the study of Growth and Employment in States [9] that rice production and processing either at macro and micro level requires substantial amount of fund. The farmers identified delay in harvesting (98.42\%), lack of technical knowledge (95.27\%), dependency on traditional threshing methods (94.48\%), incomplete threshing (91.33\%), improper handling operations $(81.10 \%)$, heavy rainfall during harvesting $(77.16 \%)$ and over or under boiling of the paddy during parboiling $(76.337 \%)$ as one of the various causes of postharvest losses in their rice production and processing in the area. This result is in line with findings of [3] that major causes of post harvest losses in rice are delay in harvest, improper handling operations, pest infestation and over drying. Moving forward, inadequate and low efficiency in the use of machinery, improper drying operations, lack of mechanical drying facilities, biological deterioration, poor defective packaging of grain, bird attack, infestation by storage pests, poor transport conditions and poor marketing system were also identified as causes of post harvest losses in rice. The finding becomes clear that their causes of post harvest losses among in rice. Addressing this problem will be critical in reducing post harvest losses, increasing income and standard of living of rice farmers in the area and beyond.

TABle 2: Major Causes of Post Harvest Losses AMONG RICE FARMERS

\begin{tabular}{|c|c|c|c|}
\hline $\mathbf{S} / \mathbf{N}$ & Causes of Post Harvest & *Frequency & Percentage \\
\hline 1 & Inadequate funding & 127 & 100.00 \\
\hline 2 & Delay in harvesting & 125 & 98.42 \\
\hline 3 & Lack of technical knowledge & 121 & 95.27 \\
\hline 4 & $\begin{array}{l}\text { Dependency on traditional } \\
\text { threshing methods }\end{array}$ & 120 & 94.48 \\
\hline 5 & Incomplete threshing & 116 & 91.33 \\
\hline 6 & Improper handling operations & 103 & 81.10 \\
\hline 7 & $\begin{array}{l}\text { Heavy rainfall during harvesting } \\
\text { and drying session }\end{array}$ & 98 & 77.16 \\
\hline 8 & $\begin{array}{l}\text { Over or under boiling of the } \\
\text { paddy during parboiling }\end{array}$ & 97 & 76.37 \\
\hline 9 & $\begin{array}{l}\text { Inadequate and low efficiency in } \\
\text { the use of machinery }\end{array}$ & 91 & 71.65 \\
\hline 10 & Improper drying operations & 88 & 69.29 \\
\hline 11 & $\begin{array}{l}\text { Lack of mechanical drying } \\
\text { facilities }\end{array}$ & 87 & 68.50 \\
\hline 12 & Biological deterioration & 84 & 66.14 \\
\hline 13 & $\begin{array}{l}\text { Poor defective packaging of } \\
\text { grain }\end{array}$ & 81 & 63.77 \\
\hline 14 & Bird attack & 76 & 59.84 \\
\hline 15 & Infestation by storage pests & 74 & 58.26 \\
\hline 16 & Poor transport conditions & 70 & 55.11 \\
\hline 17 & Poor marketing system & 62 & 48.81 \\
\hline
\end{tabular}

*Multiple Responses were recorded; Source: Field Survey Data, 2019

\section{Post-harvest management practices}

The result in Table 3 shows that rice farmers identified rice post harvest management practiced as cutting the rice stalk $(99.21 \%)$, reaping the panicles $(96.85 \%)$, laying out the paddy-on-stalk $(95.27 \%)$, stacking it to dry $(94.48 \%)$ and bundling for transport $(91.33 \%)$. These are practices involved in were involved in harvesting which is the starting point of the postharvest management process. Also, farmers identified other post harvest management of rice practiced in the area as threshing $(82.67 \%)$, drying $(74.44 \%)$, cleaning $(70.86 \%)$, milling $(70.00 \%)$ packaging $(67.50 \%)$ and storage $(62.99 \%)$. The findings became clear that farmers are becoming increasingly aware of post-harvest losses in rice and have been carefully practicing improved management strategies in the area.

Table 4 reveals the level of involvement of rice farmers in post harvest management practices by rice farmers rated in a 3 point Likert type scale of highly practiced (3); moderately practiced (2) and not practiced (1). A discriminatory mean of 2.0 was produced which divided the distribution. The most practiced post harvest management practices in the study area was cutting the rice stalk (mean $=2.71)$, farmers were highly 
involved in this, also, the farmers were involved in reaping the panicles (mean $=2.70$ ). Panicles reaping are usually done mostly by women, this is manually done by using hand-held cutting tool or knife to grab and cut the panicle stems. This implies that most farmers were more involved in cutting the rice stalk and reaping the panicles since these are the first stages of harvesting rice. The findings is in line with the study of [5] who opined that harvesting is the first operation carried out once paddy is matured. Timely and proper harvesting of matured rice panicles has been demonstrated to critical because grain loss may occur as a result of possible rodent attack, lodging and/or shattering.

TABle 3: Post Harvest Management PRACTICED By the Rice FARMERS

\begin{tabular}{clcc}
\hline S/N & $\begin{array}{l}\text { Postharvest Management } \\
\text { Practices }\end{array}$ & Frequency & Percentage \\
\hline 1 & Cutting the rice stalk & 126 & 99.21 \\
2 & Reaping the panicles & 123 & 96.85 \\
3 & Laying out the paddy-on- & 121 & 95.27 \\
& stalk & 120 & 94.48 \\
4 & Stacking it to dry & 116 & 91.33 \\
5 & Bundling for transport & 105 & 82.67 \\
6 & Threshing & 92 & 74.44 \\
7 & Drying & 90 & 70.86 \\
8 & Cleaning & 84 & 70.00 \\
9 & Milling & 81 & 67.50 \\
10 & Packaging & 80 & 62.99 \\
11 & Storage & & \\
\hline
\end{tabular}

Field Survey Data, 2019.

TABLE 4: LEVEL OF POST HARVEST MANAGEMENT PRACTICED BY RICE FARMERS

\begin{tabular}{lcccc}
\hline $\begin{array}{l}\text { Post harvest } \\
\text { Management } \\
\text { Practices }\end{array}$ & $\begin{array}{c}\text { Highly } \\
\text { Practiced } \\
(\mathbf{3})\end{array}$ & $\begin{array}{c}\text { Moderately } \\
\text { Practiced } \\
(\mathbf{2})\end{array}$ & $\begin{array}{c}\text { Not } \\
\text { Practiced } \\
(\mathbf{1})\end{array}$ & Mean \\
\hline $\begin{array}{l}\text { Cutting the rice } \\
\text { stalk }\end{array}$ & $9474.01)$ & $30(23.62)$ & $3(2.36)$ & 2.71 \\
$\begin{array}{l}\text { Reaping the } \\
\text { panicles }\end{array}$ & $9272.44)$ & $32(25.19)$ & $3(2.36)$ & 2.70 \\
Laying out the & $9373.22)$ & $28(22.04)$ & $6(4.72)$ & 2.68 \\
paddy-on-stalk & $31(24.40)$ & $89(70.07)$ & $9(7.08)$ & 2.66 \\
Packaging & $8970.07)$ & $30(23.62)$ & $8(6.29)$ & 2.63 \\
Proper threshing & $8566.92)$ & $38(29.92)$ & $4(3.14)$ & 2.63 \\
Cleaning & $80(62.99)$ & $37(29.13)$ & $10(7.87)$ & 2.55 \\
$\begin{array}{l}\text { Drying } \\
\text { Stacking it to }\end{array}$ & $89(70.07)$ & $22(17.32)$ & $16(12.59)$ & 2.40 \\
dry & & & & \\
Bundling for & $33(25.98)$ & $90(70.86)$ & $4(3.14)$ & 2.23 \\
transport & $23(18.11)$ & $87(68.50)$ & $17(13.38)$ & 2.05 \\
$\begin{array}{l}\text { Storage } \\
\text { Milling }\end{array}$ & $8(6.29)$ & $25(19.68)$ & $91(71.65)$ & 1.30 \\
\hline Disting
\end{tabular}

Discriminatory mean: Cut off point 2.0 Accepted; Figures in parenthesis are percentage; Field Survey Data, 2019.

After harvesting, the rice farmers were also involved in laying out the paddy-on-stalk (mean $=2.68$ ), then stacking it to dry (mean $=2.40$ ). In the same way, after harvest, rice is often left on the field for few days (stalking) before bundling and transporting to a cleared portion of the field and piled round to form a circle before threshing. Significant losses are usually recorded during these operations. More so, rice farmers were highly involved in threshing (mean $=2.63$ ), threshing is the operation that separates the grain from the panicle without damaging the rice, proper threshing is normally done to reduce losses in rice. This is either done manually or mechanically, most of the small scale farmers did it manually by either treading, beating the panicles with stick.
Rice farmers practiced drying (mean $=2.55$ ) as one of the post harvest management practices, drying is normally done to remove the moisture content of rice, this makes threshing easier. Rice farmers involve in drying of harvested grain for about two days for proper storage to reduce fungi infestation and improve the quality of rice. Also, farmers were involved in bundling for transport (mean $=2.23$ ) as one of the post harvest management practiced in the area, these were done to prevent considerable amount of post production loss.

Involvement of farmers in cleaning (mean $=2.63$ ) as one of the post harvest management practice was observed. Cleaning of grain involves the separation of unwanted elements from rice such as removal of bulk straw, chaff, empty kernels, and very light and fine impurities from the grain. Marvin et al [12] views that for proper storage and processing, cleaning is essential it improves the quality of rice and probably increase the market price of the rice.

Farmers were also involved in rice milling $($ mean $=1.30)$, this result is expected as rice milling is the removal or separation of the husk (dehusking) and the bran (polishing) to produce the edible portion (endosperm) for consumption. Few farmers were directly involved in milling due to lack of machinery involved in milling, only few farmers could afford the milling machines. Rice farmers were involved in packaging $($ mean $=2.66)$, most farmers were subsistence farmers, the threshed and partially cleaned rice is bagged in jute or propylene sacks for handling purposes in transporting rice from the field to the roadside or to the house. Furthermore, the rice farmers practiced storage $($ mean $=2.05)$ as one of the post harvest management practices in the study area. Proper storage is done to reduce pest and fungi infestation. Storage is an important part of postharvest process in rice to ensure and guarantee rice quality.

\section{Constraints to post harvest management practices of rice}

The various constraints to post harvest management practices faced by rice farmers were identified in Table 5 . The constraints were rated in a 3 point Likert type scale of very serious (3); moderately serous (2) and not serious (1). A discriminatory mean of 2.0 was produced which divided the distribution. By these criteria, all the attributes were related to constraints to post harvest management practices faced by rice farmers. The farmers reported that the major constraint was cumbersome techniques $(\mathrm{M}=2.75)$ of some of the post harvest management practices. This implies that farmers perceived some of the techniques overloaded and this reduced the efficiency of the good post harvest practices. Also, the farmers perceived lack of awareness of good post harvest practices and technology $(\mathrm{M}=2.68)$, inadequate machinery $(\mathrm{M}=2.67)$, pest and disease problems $(\mathrm{M}=2.67)$, non cost effectiveness of storage technology $(M=2.65)$, inadequate financial support $(M=2.59)$, lack of economic incentives to store rice $(\mathrm{M}=2.58)$, inadequate extension support $(\mathrm{M}=2.64)$, and lack of technical know-how $(\mathrm{M}=2.59)$ as problems encountered in post harvest management practices. This finding shows a positive and significant discriminatory mean of 2.0 and above across all the constraints items rated. This implies that farmers face this constraints across all the items rated. This is in line with the study of who observed that 
most constraints to good post harvest management practices are pest and disease attack in stored grains, lack of extension services in modern post harvest management practices, high cost of machinery and lack of capitals. These constraints are the major reason why farmers face huge losses in rice production and processing. If these constraints are systematically addressed, it will reduce post harvest losses, increase their income, improved food security and standard of living of farmers in the area.

Table 5: Constraints to Post Harvest Management PRaCtices of

\begin{tabular}{|c|c|c|c|c|}
\hline Constraints & VS (3) & MS(2) & NS(1) & Mean \\
\hline Cumbersome techniques & $88(69.2)$ & $31(24.40)$ & $8(6.29)$ & 2.75 \\
\hline $\begin{array}{l}\text { Lack of awareness of good } \\
\text { post harvest practices and } \\
\text { technology }\end{array}$ & $92(72.4)$ & $32(25.19)$ & $2(1.57)$ & 2.68 \\
\hline Inadequate machinery & $91(71$. & $31(24$. & $5(3.93)$ & 2.67 \\
\hline Pest and disease problems & $91(71.6)$ & $31(24.40)$ & $5(3.93)$ & 2.67 \\
\hline $\begin{array}{l}\text { Non cost effectiveness of } \\
\text { storage technology }\end{array}$ & $93(73.2)$ & $27(21.25)$ & $4(3.14)$ & 2.65 \\
\hline Inadequate extension support & $86(67.7)$ & $37(29.13)$ & $4(3.14)$ & 2.64 \\
\hline Lack of technical know how & $86(67.7)$ & $32(25.1$ & $9(7.08)$ & 2.59 \\
\hline Inadequate financial support & $81(63.7)$ & $38(29.92)$ & $10(7.8)$ & 2.59 \\
\hline Lack of economic incentives & $90(70.8)$ & $24(18.89)$ & $10(7.8)$ & 2.58 \\
\hline
\end{tabular}

Note VS $=$ Very Serious, $\mathrm{MS}=$ Moderately Serious, $\mathrm{NS}=$ Not Serious Discriminatory mean: Cut off point 2.0 Accepted; Figures in parenthesis are percentage; Field Survey Data, 2019.

\section{E. Influence of farmers socio-economic characteristics on number of post harvests management practiced}

Table 6 shows the influence of socio-economic characteristics on number of post harvests management strategies practices. The result from the multiple regression analysis showed that age, educational level, membership of cooperative, household size, farming experience, household size, farming experience and access to credit were found to have significantly influenced the number of post harvests management practiced by farmers. This compels the researcher to rejecting the null hypothesis of the study which states that, there is no significant relationship between farmers socio-economic characteristics and number of post harvests management practiced in the study area. The coefficient of multiple determination $\left(\mathrm{R}^{2}\right)$ was found to be $94.70 \%$ and was statistically significant at $1 \%$ level of probability. This implies that the socio-economic characteristic of farmers had a significant influence on the number of post harvests management practices adopted and that the regression model has a very high and strong explanatory power. This is an indication that approximately $94.70 \%$ of the variation in number of post harvests management practices adopted by farmers was explained by the explanatory variables. Hence the researcher concludes that the socio-economic characteristic of rice farmers influences the number of post harvests management practiced adopted by the farmers in the study area.

\section{IV.CONCLUSION \& RECOMMENDATIONS}

Achieving food security is one of the programme of any country, since rice is one of the major staple food of a nation, there is need to minimize losses in rice production. This study identify different constraints to post harvest management practices such as lack of awareness of good post harvest practices and technology, inadequate machinery, lack of incentives to store. If these constraints are systematically addressed, it will reduce post harvest losses, increase their income, improved food security and standard of living of farmers in the area. Therefore, based on the findings from this study, the following recommendations were made: Extension agents should be encouraged to increase their campaign on post harvest management practices of rice and organize more training on minimization of post harvest losses on rice. Also, loans and grants should be provided to the rice farmers to enable them to hire more labour in post harvest management practices, purchase new machine and adopt new technologies and techniques. Other incentives such as provision of processing and storage facilities, provision of market avenues, should be made available to the farmers so as to prevent or reduce post harvest losses. Agricultural engineers should be encouraged to design and develop indigenous machines that are suitable for minimizing rice loss.

TABLE 6: INFLUENCE OF FARMERS SOCIO-ECONOMIC CHARACTERISTICS ON Number of POST HARVESTS MANAGEMENT PRACTICES ADOPTED

\begin{tabular}{lll}
\hline Explanatory Variables & Coefficients & T-value \\
& & \\
\hline Constant & 0.954 & $-.3457 * *$ \\
Age $\left(\mathrm{X}_{1}\right)$ & -0.003 & -2.004 \\
Level of Education $\left(\mathrm{X}_{2}\right)$ & 0.347 & $2.807 * *$ \\
Cooperative Membership $\left(\mathrm{X}_{3}\right)$ & 0.870 & $4.903^{* *}$ \\
Marital Status $\left(\mathrm{X}_{4}\right)$ & -0.595 & -0.967 \\
Household Size $\left(\mathrm{X}_{5}\right)$ & 0.946 & $3.119^{* *}$ \\
Farming Experience $\left(\mathrm{X}_{6}\right)$ & 0.581 & $5.056^{* *}$ \\
Access to Credit $\left(\left(\mathrm{X}_{7}\right)\right.$ & 0.914 & $4.152^{* *}$ \\
Sex $\left(\mathrm{X}_{8}\right)$ & 0.381 & 0.678 \\
R2 & 94.70 & \\
F-Ratio & $17.018 * *$ & \\
\hline Significant at $5 \% ; * *$ Significant & $1 \%$ & \\
\hline
\end{tabular}

* Significant at 5\%; ** Significant at $1 \%$

\section{REFERENCES}

[1] O. Agada and B.E. Ijih, "Analysis of Post Harvest Management Practices among Farmers in Oju, Benue State, Nigeria”. Journal of Agriculture and Environmental Sciences, Vol. 8(1), 2019.

[2] H.O. Akaeze, "Consumer Preference for Imported Rice in Nigeria, Perceived quality, differences or habit persistence". M.Sc thesis, Michigan State University, 2010.

[3] S. Ayado, " Discordant tunes over Yam Export Policy in Nigeria". Article Published in the Leadership Newspaper 19th June, 2017.

[4] C, Chukwunta, "An Analysis of Post Harvest Losses Management Strategies by Farmers in Awgu Local Government Area of Enugu State Nigeria". University of Nigeria, Nsukka, 2014

[5] N. Danbaba, P.Y. Idakwo, A.L.Kassum, C. Bristone, S.O. Bakare, U. Aliyu, I.N. Kolo, M.E. Abo, A. Mohammed, A.N. Abdulkadir, I Nkama, M.H. Badau, M.A. Kabaraini, H. Shehu, A.O. Abosede and M.K.Danbaba, "Rice Postharvest Technology in Nigeria: An Overview of Current Status, Constraints and Potentials for Sustainable Development", 2015. Open Access Library Journal, 6 : e5509.https://doi.org/10.4236/oalib.1105509

[6] C.C. Eze, B. Amanze, and O. Nkwankwo, "Resource Use Efficiency in Arable Crop production among Small Holder Farmers in Owerri Agricultural Zone of Imo State, Nigeria". Research 2(5) pp 14-20, 2010 .

[7] Food and Agricultural Organisation, Global Food Losses and Food Waste-Extent, Causes and Prevention. Rome, 2011.

[8] J.A. Folayan, "Determinants of Post Harvest Losses of Maize in Akure North Local Government Area of Ondo State, Nigeria". Journal of Sustainable Society 2(1), 2013: 2168-2585.

[9] Growth and Employment in States, Mapping of Rice Production Clusters in Nigeria. A Project Report on Growth and Employment in 
States by the United Kingdom Department of International Development (DFID) in Nigeria, 66, 2017.

[10] R. Guise, Post Harvest Losses of Rice (Oriza Spp) from Harvesting to Milling: A Case Study in Besease and Nobewam in The Ejisu Juabeng District in the Ashanti Region Of Ghana, 2010.

[11] L, Kitinoja, and J.R. Gorny, Post harvest technologies for small scale horticultural farmers and marketers: economic opportunistic, quality and food safety. University of California post harvest horticultural series. No. 21, 2010.

[12] R.P. Marvin, K.K. Prasanta and D.R. Kent, "Postharvest losses due to Harvesting Operations in Developing Countries": A review of American Society of Agricultural and Biological Engineers Annual International Meeting Held at New Orleans, United States, Published by American Society of Agricultural and Biological Engineers 1(1): 562-596, 2015.

[13] Nigerian Population Commission, Nigerian Federal Government Initiative of individual Head Count. Spread, State by State, 2006.

[14] J.C. Norman, and B. Kebe, African Smallholder Farmers: Rice Production and Sustainable Livelihoods. International Rice Commission Newsletter (FAO), 55: 33-44, 2006.

[15] A.E. Oguntade, D. Thyimann, and S. Deimling, "Postharvest Losses of Rice in Nigeria and their Ecological Foot Print". Federal Ministry of Economic Cooperation and Development. Deutsche Gesellschaft fur Internatinale Zusammenarbeit (GIZ), German Food Partnership/Competitive African Rice Initiative (CARI), 51, 2014.

[16] West African Rice Development Association, Rice, a Strategic Crop for Food Security and Poverty Alleviation, 2015. Available from www2.slu.se/cigar/CGIAR_WARDAppt.

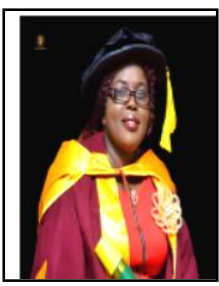

Dr. Helen A. Egwuonwu holds a $\mathrm{PhD}$ in Agricultural Extension and Rural Development from Federal University of Technology, Owerri, Nigeria in 2017. She both obtained her M.Agric. (Agricultural Extension) in 2005 and B.Agric. in 2000 from Federal University of Agriculture Abeokuta, Nigeria. Dr. Helen Egwuonwu is currently lecturing in Imo State University, Owerri, Nigeria. Her research interests are in agriculture, gender, community and rural development. She is a member of a professional body, Agricultural Extension Society of Nigeria (AESON) 